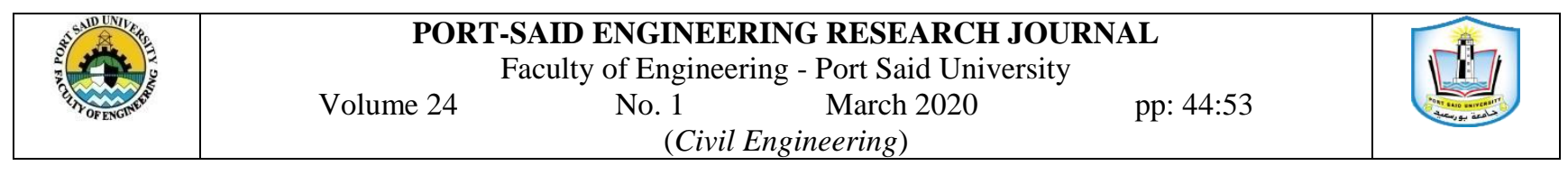

\title{
Modeling of Large Diameter Piles in Soil Formations Including Soft Clay
}

\author{
Tarek N. Salem ${ }^{1}$, Khaled M. Abdelatty ${ }^{2}$, Nour A. Aboshita ${ }^{3}$
}

\begin{abstract}
In Egypt, large diameter piles are used in some sites with diameters exceeding $2 \mathrm{~m}$. In some cases, these piles carry foundations of heavy structures and/or large vertical and lateral loads. The analysis and design methodologies of large diameter piles are mainly controlled by the relatively smaller diameter piles, usually ranging between 60 and $120 \mathrm{~cm}$. However, there is a special need for the analysis and design of larger diameter piles (i.e., larger than $120 \mathrm{~cm}$ ) to assess their actual load carrying capacities. This paper presents numerical modeling of end bearing piles constructed in thick layer of soft to very soft clay underlain by a dense sand layer, typical to large zones in Northern and North Eastern zones in Egypt. The finite element analysis software ADINA (2018) [2] is used to simulate the behavior of the large diameter bored piles. Results showed that increasing the pile diameter cause a corresponding increase in pile capacity. It is also noticed that increasing pile embedded length in the end bearing sand layer has an enormous effect on pile capacity especially for larger diameter piles.
\end{abstract}

KEYWORDS: Large Diameter Piles, Pile Load Test, Soft Clay, Cam-Clay, ADINA.

\section{INTRODUCTION}

Deep layers of soft to very soft clay are covering large zones of the Egyptian northern coast. Due to low bearing capacity of soil and expected high settlement of heavy structures, large diameter piles can be used as an appropriate solution for the foundation on soil formations including a deep layer of soft clay.

O'Neill and Reese (1999) [12] defined large diameter piles as those with diameters larger than $760 \mathrm{~mm}$. According to the Egyptian code of practice (ECP (2022005)) [7], bored piles with diameters larger than 600 $\mathrm{mm}$ are considered large diameter piles. The design of these piles depends on the results of the pile load test. If it is not possible to perform the pile load test to be used in the design phase, ECP (202-2005) [7] suggests a design criterion to estimate the pile load-settlement relationship depending on the soil type and pile diameter.

The vast advances in piling technology made the installation cost of bored piles lower than before. Despite of that it is strongly believed that the design of large diameter pile is conservative. (Lee and Salgado, 1999) [11].

In working stress design, a relatively high factor of safety is used because of the high level of uncertainty associated with loads and capacities of large diameter deep foundations. Thus, this relatively high factor of safety should be replaced by a probability-based design approach such as the Load Resistance Factor Design (LRFD) which should be used in geotechnical designs (AbdelSalam and El-Naggar, 2014) [1].

\footnotetext{
${ }^{l}$ Professor, Faculty of Engineering, Zagazig University, Egypt, Email: nageeb2@yahoo.com

${ }^{2}$ Lecturer, Faculty of Engineering, Zagazig University, Egypt, Email: khaled.abdelatty@gmail.com

${ }^{3}$ Demonstrator, Higher Institute of Engineering and Technology-Al Arish, Egypt, Email: nouraboshita@yahoo.com
}

The failure criteria of large diameter piles are generally based on the pile head movement. For piles in cohesionless soil, the failure load is defined in many studies as follows:

Weltman (1980) [17], Smoltczyk (1985) [15], BSI (1986) [5] defined the failure load as the load corresponding to a pile-head settlement equal to $10 \%$ of the pile diameter. They implied that the failure load they suggested may not be possible to achieve in practice, especially in end bearing piles in dense sand. Kulhawy and Hirany (1989) [10] tested a group of board piles with diameters ranged from 0.4 to $1.1 \mathrm{~m}$ with length less than $17 \mathrm{~m}$. Using the load settlement curves of these tests to define the failure load as the load corresponding to pile head settlement of $4 \%$ of the pile diameter. ASTM D1143-81 (1994) [3] defined the pile failure load at which the axial movement equals to $15 \%$ of the pile diameter or width, which is even higher than the previously stated limit, and consequently harder to achieve. O'Neill and Reese (1999) [12] defined the failure load based on experimental studies as the load corresponding to a total settlement of $5 \%$ of the pile diameter.

\section{NUMERICAL MODEL}

Finite Element Method (FEM) is widely used in predicting the behavior of axially loaded piles (Chung et al., 2012) [6]. In this study, the results from an axisymmetric two-dimensional analysis of piles bearing in dense to very dense sand are presented. The numerical analysis is performed using Automatic Dynamic Incremental Nonlinear Analysis (ADINA) Ver. 9.4.2 computer program (ADINA R \& D, 2018) [2]. Since the model is rotationally symmetric about an axis, axisymmetric elements are used to model the structural elements (Bathe, 2014) [4]. The axisymmetric element represents one radian of the structure so that the stiffness, mass and loads should be defined accordingly. 


\subsection{Geometry and Boundary Conditions}

The selected model dimensions are 25 times the pile diameter in the horizontal direction and to be at least 1.50 times the pile length below the pile tip along the vertical direction to overcome the boundary effect (Randolph, 1978) [14]. The two vertical side boundaries are fixed against horizontal movement and all rotations, but allowed for vertical displacement (settlement) to take place. The horizontal bottom boundary is fixed against all vertical and horizontal displacements and all rotations. Figure (1) illustrates a typical model dimensions and boundary conditions.

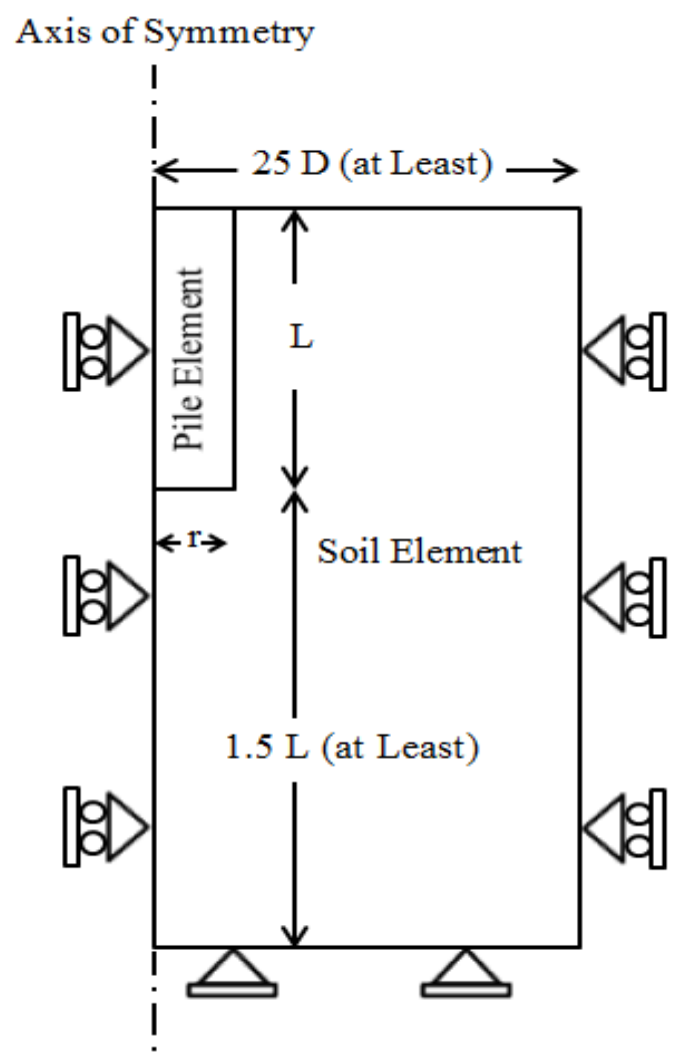

Figure (1): Schematic View of the Boundary Conditions and Dimensions Used in the Numerical Modeling.

\subsection{Finite Element Model}

Two-dimensional solid elements are used to represent the soil and the pile elements. Since the bending effects are not significant, the 4-node rectangular element is used. A zone of very fine mesh is used around and below the pile, and equal to three times the pile diameter in each direction. The mesh size around the pile is approximately 0.2 $\mathrm{m}$ and gradually increased to approximately $1.0 \mathrm{~m}$ at the boundaries. The pile mesh is divided into three equal elements. Figure (2) shows the finite element mesh around the refined zone.

As the material of the pile is concrete, it is modeled using the linear elastic isotropic model or the concrete model. To best present the characteristics of the dense sand layer, it is modeled using Mohr-Coulomb (M-C) material model. On the other hand, Cam-Clay (C-C) material model is used to model the soft and very soft.

To define contact interfaces, a contact element group is first defined, and then surfaces within that group are defined to represent lines or edges of bodies. Next, contact pairs of two surfaces that may come in contact are defined for a contact group. In each pair one surface is selected as the target surface and one surface is the contactor surface. In this study, the friction coefficient is taken 0.50 for sandy soil and 0.25 for clayey soil.

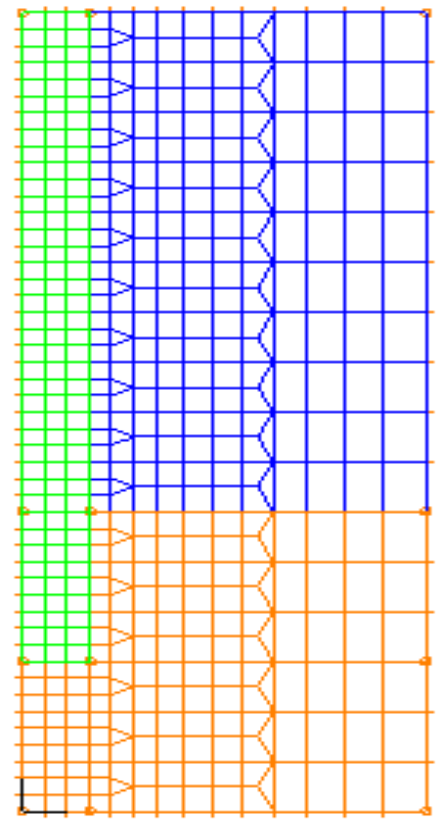

Figure (2): Zoom on the Refined Finite Element Mesh around the Pile.

\subsection{Modeling of Construction Sequence}

The analysis is performed over three phases to account for the pile construction and loading sequence. The first phase simulates the soil initial geostatic stress by applying the mass proportional load in a porous media analysis to model the settlement due to its own weight before the pile construction begins. The second phase begins with constructing the pile in which case the soil elements at the pile position is set to death and the pile elements are being set to birth through the birth/death option. The third phase of the analysis is conducted by applying the load gradually at the pile head.

\subsection{Verification of the Finite Element Model}

A full scale pile load test is performed in Port-Said city on a pile with diameter and length of $1.2 \mathrm{~m}$ and 70.0 $\mathrm{m}$ respectively. Different investigations proved that the sand layer at depth -70 in the borehole under study is extended to $-90 \mathrm{~m}$ (Hamed et al., 2017 [9] and Golder Associates, 1979 [8]). The location of the pile load test used in the verification in this study is as shown in Figure (3). The pile is loaded with $12000 \mathrm{kN}$ and settled by $26.25 \mathrm{~mm}$ (Radwan et al., 2007) [13]. The borehole data and soil properties are shown in Figure (4). The groundwater table is at $4.0 \mathrm{~m}$ depth below the ground surface. 


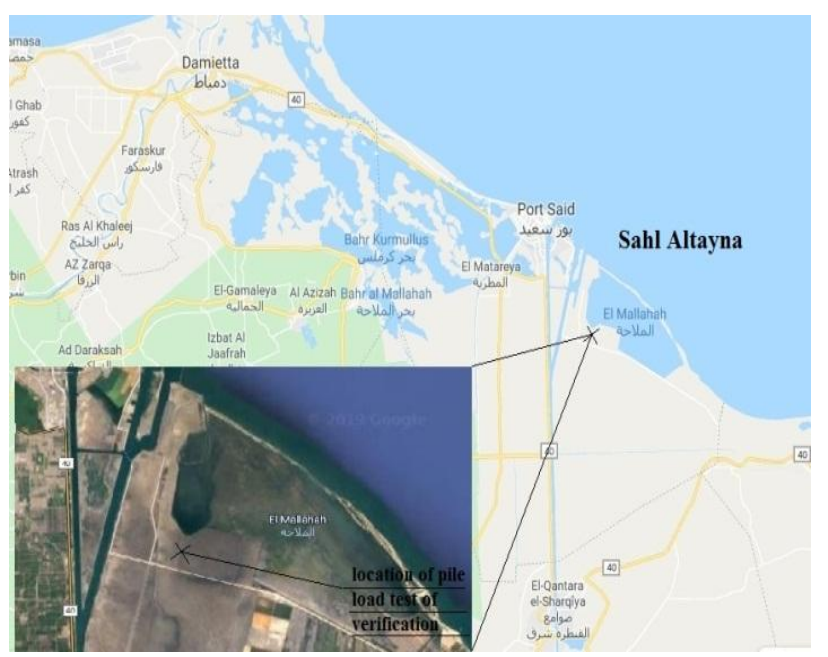

Figure (3): Pile Load Test Location.

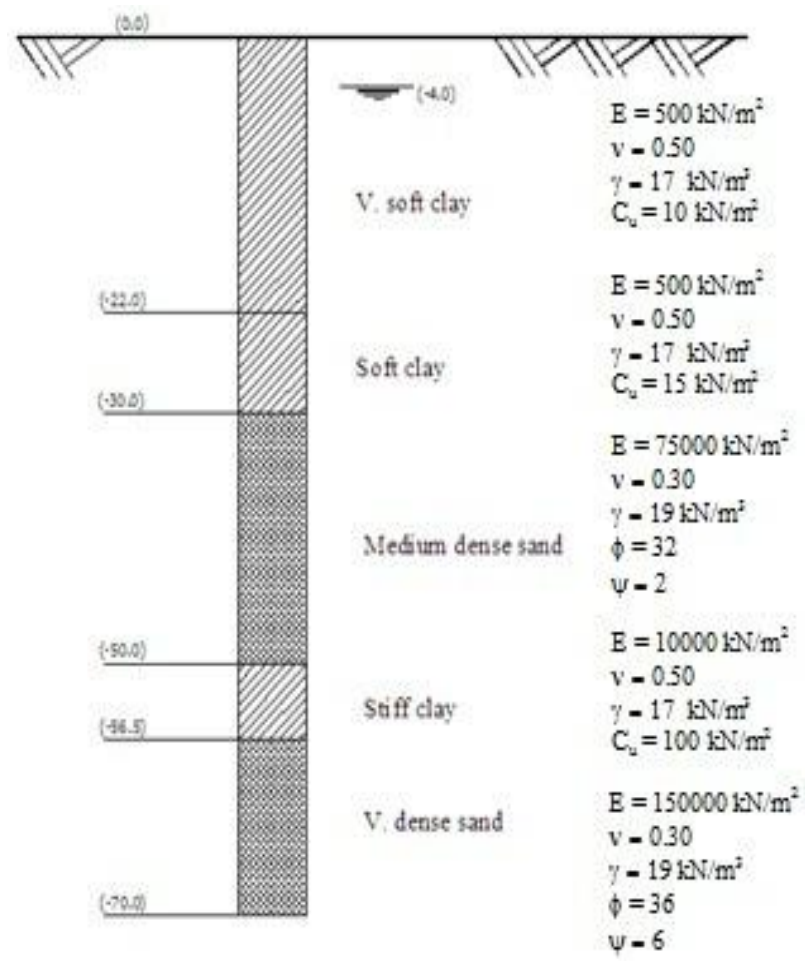

Figure (4): Borehole Data and Soil Properties at the Pile Load Test Site (after Radwan et al., 2007) [13].

The measured displacement and the computed one resulted by the ADINA finite element program are compared as presented in Figure (5). Results of the numerical model show a computed settlement of 23.01 mm under maximum load of $12000 \mathrm{kN}$. In these results the actual soil movement (settlement) relative to the pile is considered in the numerical model, and thus the negative skin friction caused due to existence of soft clay is considered in the analysis. On the other hand, the measured settlement in the pile load test at the same load was $(26.25 \mathrm{~mm})$ with a maximum difference of about $12.3 \%$. Good agreement is noticed between the pile load test results and the numerical model especially under higher stress levels. However, a maximum difference of about $40 \%$ is noticed at some points in the lower stress levels.

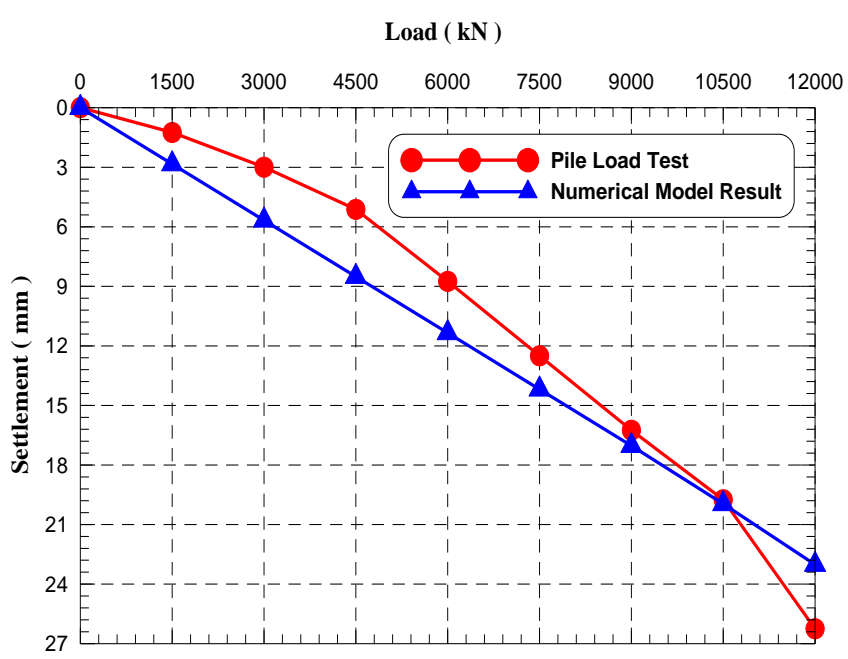

Figure (5): Load-Settlement Relationship for the Pile Load Test and the Numerical Model Results.

The settlement due to pile loading only is shown in Figure (6). It should be noted that the depth of the affected settlement zone is about six times the pile diameter under the pile tip.

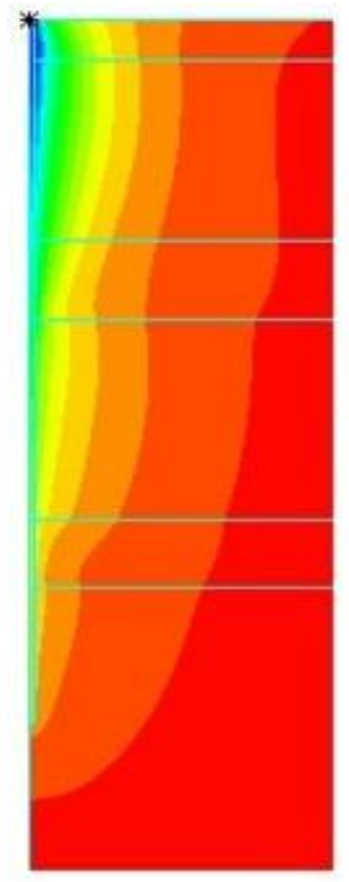

\section{Z-DISPLACEMENT \\ Response combination}

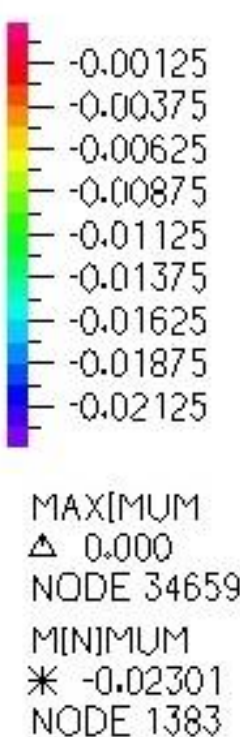

Figure (6): Color Shaded Contours of Vertical Displacement around the Pile.

The vertical stress distribution in $\mathrm{N} / \mathrm{m}^{2}$ at the final phase of the analysis is shown in Figure (7). It is noticed that stresses are mostly concentrated along the pile shaft and a stress blub of relatively low stress appeared just below the pile tip of a depth of about 2.0 times the pile diameter, and a width of about 2.2 times the pile diameter. As we can see, the soil did not reach the yield stage due to the large pile length and the existence of layers like medium dense sand and stiff clay, so the skin friction in such case could be higher than the end bearing. The total load transferred by skin friction is about $88 \%$ and about $12 \%$ by end bearing. 


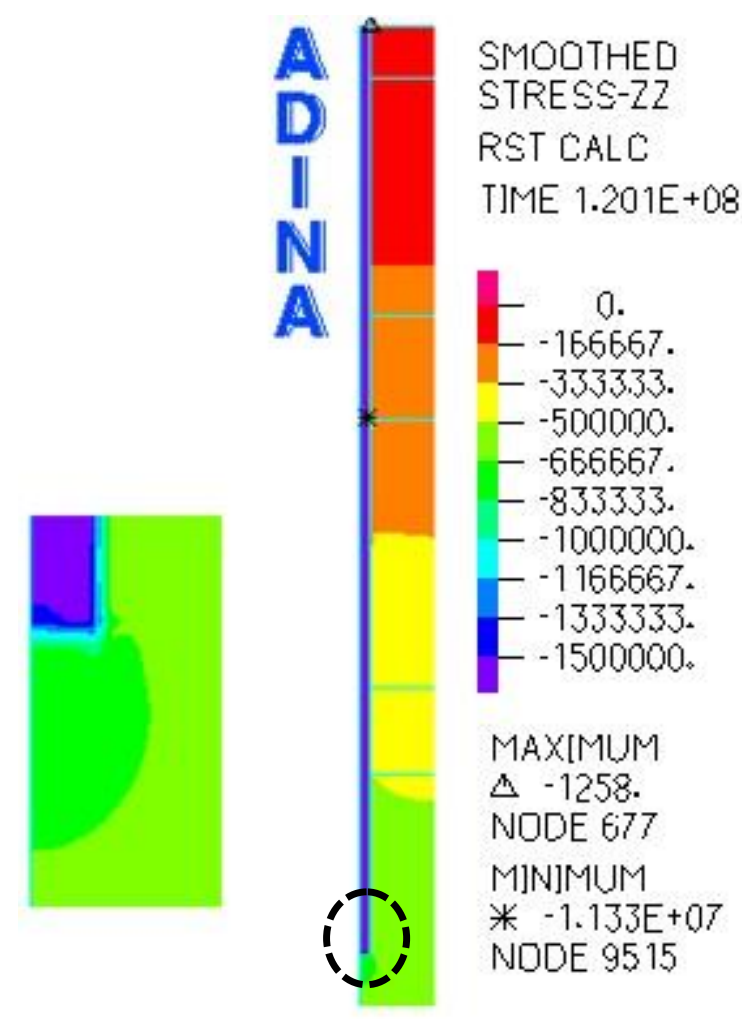

Figure (7): Color Shaded Contours of Vertical Stress along the Pile.

\section{THE PROPOSED SOIL PROFILE}

The soft clay layer located in Port-Said extends to depths ranging between $30.0 \mathrm{~m}$ to $50.0 \mathrm{~m}$ below ground surface in different locations (Hamed et al., 2017 [9] and Radwan et al., 2007 [13]) as shown in Figure (4). The soil profile, in the current study, is simplified into two layers only. The first layer is soft clay, extending to a depth of $40 \mathrm{~m}$ below ground surface followed by a layer of very dense sand extending to a great depth, and the ground water table is considered to be at the ground surface. The soil properties and the proposed soil profile are summarized in Table (1).

Table (1): Soil Properties and the Proposed Soil Profile.

\begin{tabular}{|c|c|c|c|}
\hline \multirow{2}{*}{$\begin{array}{c}\text { Layer } \\
\text { Depth }(\mathrm{m})\end{array}$} & $\begin{array}{c}\text { Layer } \\
\text { Description }\end{array}$ & \multicolumn{2}{|c|}{ Layer Properties } \\
\cline { 3 - 4 } & & $\mathrm{N}_{30}$ & $\mathrm{C}_{\mathrm{u}}(\mathrm{kPa})$ \\
\hline $0.0-40.0$ & Soft Clay & - & 15 \\
\hline 40.0 - Extended & $\begin{array}{c}\text { Very Dense } \\
\text { Sand }\end{array}$ & $>50$ & - \\
\hline
\end{tabular}

The modulus of elasticity of the studied concrete pile is assumed to be $24000 \mathrm{MPa}$ with Poisson's ratio of 0.20 . Piles with lengths from 45 to $60 \mathrm{~m}$ and with diameters ranging between $0.6 \mathrm{~m}$ to $2.5 \mathrm{~m}$ are studied in the analysis.
The pile head settlement $\delta$, expressed as a ratio of the pile diameter $\mathrm{D}$, is used to define the failure load. Different settlement-diameter ratios are considered in the analysis ranging from $1.0 \%$ to $3.5 \%$ of the pile diameter to cover the practical settlement range in end bearing piles. The lower limit ratio is considered because it is the settlement at the working load (Vesic, 1970) [16]. The upper limit ratio is considered because it is close to the failure criteria proposed by Kulhawy \& Hirany (1989) [10] and O'Neill \& Reese (1999) [12], which is 5\% of the pile diameter. Also, beyond such ratio range, it is difficult for the numerical model to converge, especially for larger diameters. For practical purposes it is also understandable that other design criteria with $(\delta / D)$ of $10 \%$ or even higher would not be achieved.

\section{ANALYSIS OF THE RESULTS}

\subsection{Effect of Pile Diameter on the Pile Capacity}

Results of the numerical model show a consistent increase in the pile load carrying capacity with increasing the pile diameter for different settlement to diameter ratios, as shown in Figure (8). It is noticed that increasing the pile diameter from $0.6 \mathrm{~m}$ to $0.8 \mathrm{~m}$, from $0.8 \mathrm{~m}$ to 1.0 $\mathrm{m}$, from $1.0 \mathrm{~m}$ to $1.2 \mathrm{~m}$ and from $1.2 \mathrm{~m}$ to $1.4 \mathrm{~m}$ increases the pile load capacity by about $117 \%, 77 \%, 55 \%$ and 31 $\%$ respectively at $(\delta / \mathrm{D})$ equal to $1.0 \%$. On the other hand, when $(\delta / D)$ is increased to $3.5 \%$, the pile load capacity increases by about $83 \%, 52 \%, 37 \%$ and $29 \%$ respectively. It is noticed that increasing $(\delta / D)$ resulted in increasing the pile load capacity but with lower rate. Increasing the pile diameter from $1.4 \mathrm{~m}$ up to $2.5 \mathrm{~m}$ resulted in a consistent increase in the pile load carrying capacity by about $20 \%$ for each diameter increment, as shown in Figure (8).

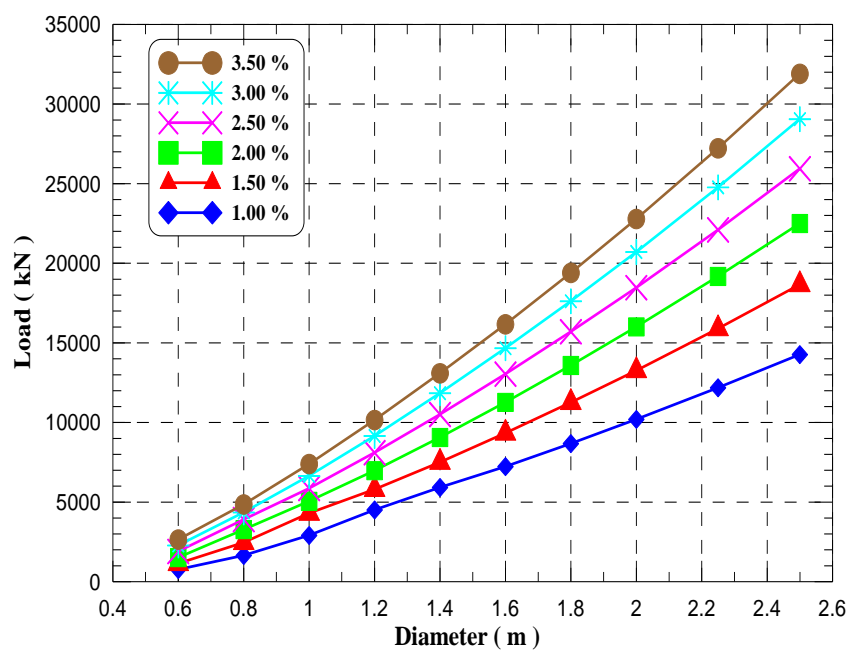

Figure (8): The Relationship between Pile Diameter (m) and Applied Load $(\mathrm{kN})$ at Different Settlement-Diameter Ratios for Pile Length Equal to $50 \mathrm{~m}$.

Distribution of vertical stress due to the third stage only for piles with diameters $1.20 \mathrm{~m}$ and $1.40 \mathrm{~m}$ is shown in Figure (9). As we can see as the pile diameter increases, the stresses transferred to the soil at the pile tip and along the pile shaft increase. Hence, the piles load capacity increases. 


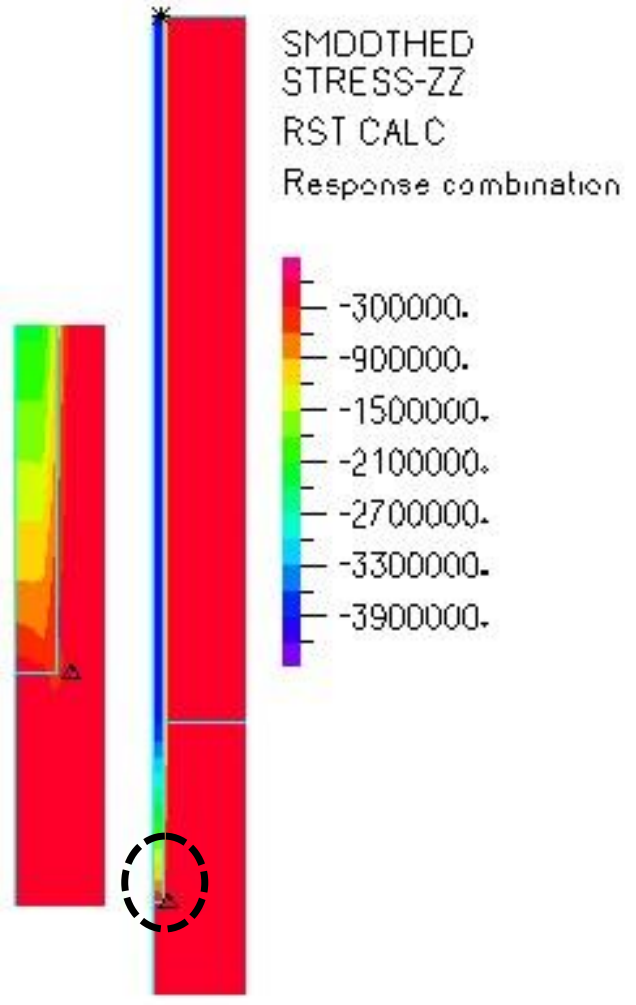

Figure (9-a): Color Shaded Contours of Vertical Stress along the Pile Length with Diameter $1.20 \mathrm{~m}$ at $(\delta / \mathrm{D})=$ $1.0 \%$.

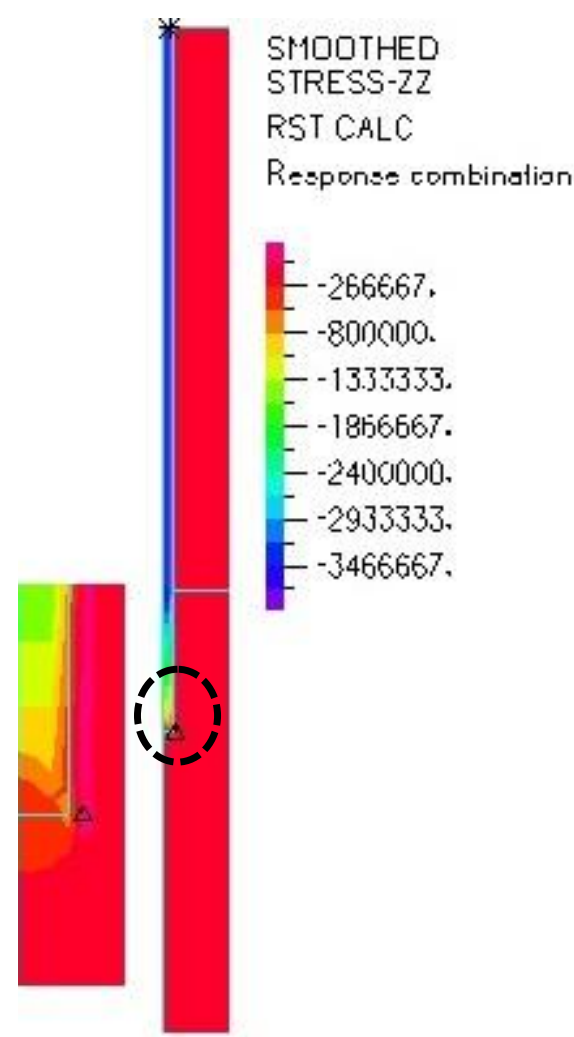

Figure (9-b): Color Shaded Contours of Vertical Stress along the Pile Length with Diameter $1.40 \mathrm{~m}$ at $(\delta / \mathrm{D})=$ $1.0 \%$.

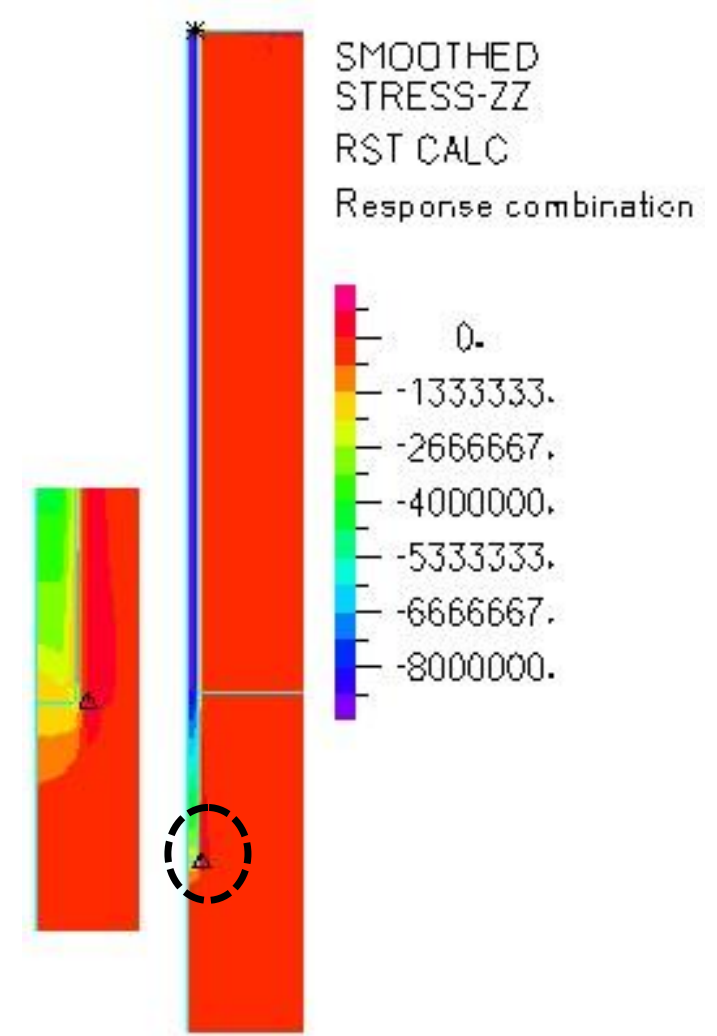

Figure (9-c): Color Shaded Contours of Vertical Stress along the Pile Length with Diameter $1.20 \mathrm{~m}$ at $(\delta / \mathrm{D})=$ $3.5 \%$.

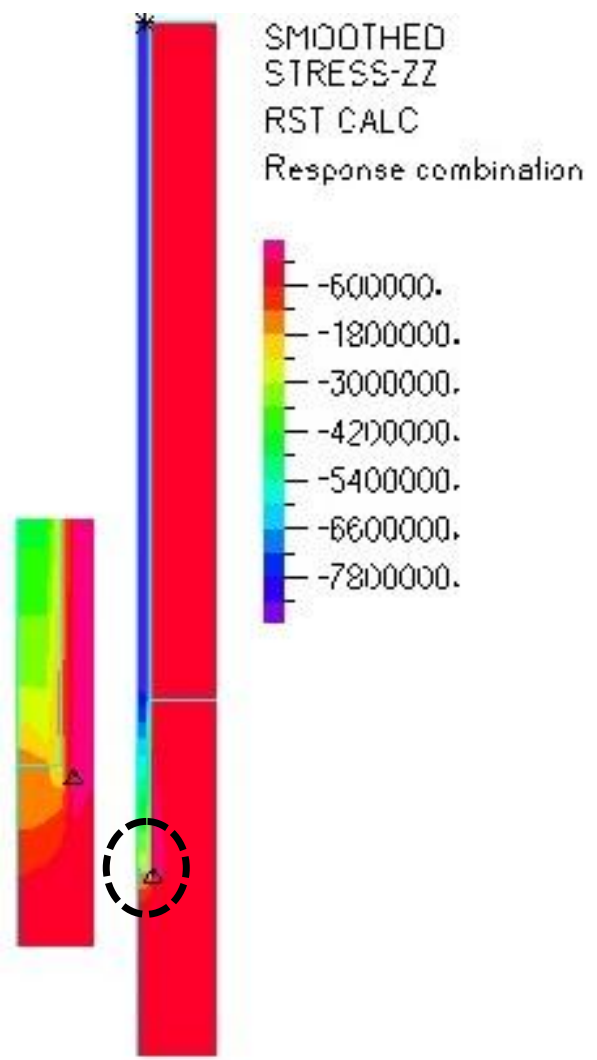

Figure (9-d): Color Shaded Contours of Vertical Stress along the Pile Length with Diameter $1.40 \mathrm{~m}$ at $(\delta / \mathrm{D})=$ $3.5 \%$.

Figure (9): Color Shaded Contours of Vertical Stress of Pile Diameter $1.20 \mathrm{~m}$ and $1.40 \mathrm{~m}$ at Pile Length Equal to $50.0 \mathrm{~m}$. 
The relationship between the pile diameter and the end bearing stress transferred to the soil at the pile tip at different settlement-diameter ratios is shown in Figure (10). Increasing the pile diameter increases the end bearing stresses transferred to the underlying soil. It is noticed that when increasing the pile diameter from 0.60 $\mathrm{m}$ till $1.4 \mathrm{~m}$ the end bearing stress increases gradually at a relatively high rate until $(\delta / D)$ equals to $2.0 \%$. However, the increase in the end bearing stress is slight for higher $(\delta / D)$ ratios. This is attributed to the fact that in such case most of the pile capacity is gained from the skin friction. Increasing the pile diameter from $0.6 \mathrm{~m}$ to $1.4 \mathrm{~m}$ increases the end bearing stress by about $61 \%$ but increasing pile diameter from $1.4 \mathrm{~m}$ to $2.5 \mathrm{~m}$ increases the bearing stress by about $14 \%$ at $(\delta / D)$ equal to $1.0 \%$. At $(\delta / \mathrm{D})$ equal to $3.5 \%$, increasing the pile diameter from $0.6 \mathrm{~m}$ to $0.8 \mathrm{~m}$ increases the end bearing stress by about 4 $\%$ and increasing from $0.8 \mathrm{~m}$ to 2.5 increases the end bearing stress by about $13 \%$ only. However, higher end bearing stresses will take place after the skin friction reaches its yield values.

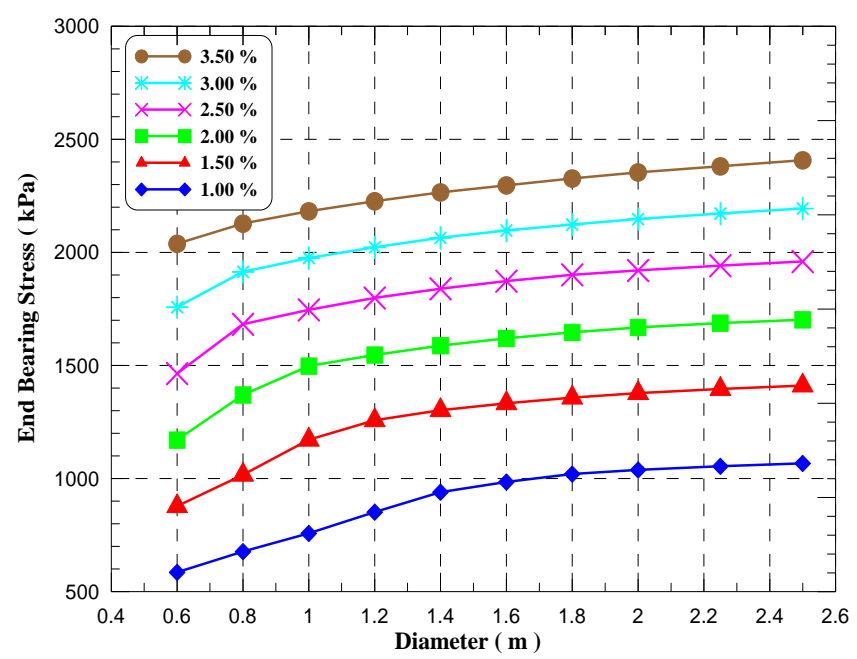

Figure (10): The Relationship between the Diameter and End Bearing Stress at Different Settlement-Diameter Ratios at Pile Length Equal to $50 \mathrm{~m}$.

The relationship between the pile diameter and the stress transferred to the soil as skin friction along the pile shaft at different settlement-diameter ratios is shown in Figure (11). It is noticed that there is a consistent increase in the skin friction stress when increasing the pile diameter from $0.60 \mathrm{~m}$ till reaching $1.4 \mathrm{~m}$, after which the rate of increase becomes less pronounced. At lower settlement $(\delta / \mathrm{D}=1.0 \%)$, the increase in the mobilized skin friction is slight and less pronounced. However, for higher settlements $(\delta / D=3.5 \%)$, the mobilized skin friction is increasing consistently at a pronounced higher rate. Combining this behavior with the previously noticed lower mobilized end bearing stresses indicates that at working load conditions, most of the pile load carrying capacity is gained from the mobilized skin friction values. The mobilization of the full end bearing stresses are associated with much higher settlements, which explains defining the pile failure load at settlements equal to $10 \%$ of the pile diameter. Reaching these settlements grantees the full mobilization of friction resistance.

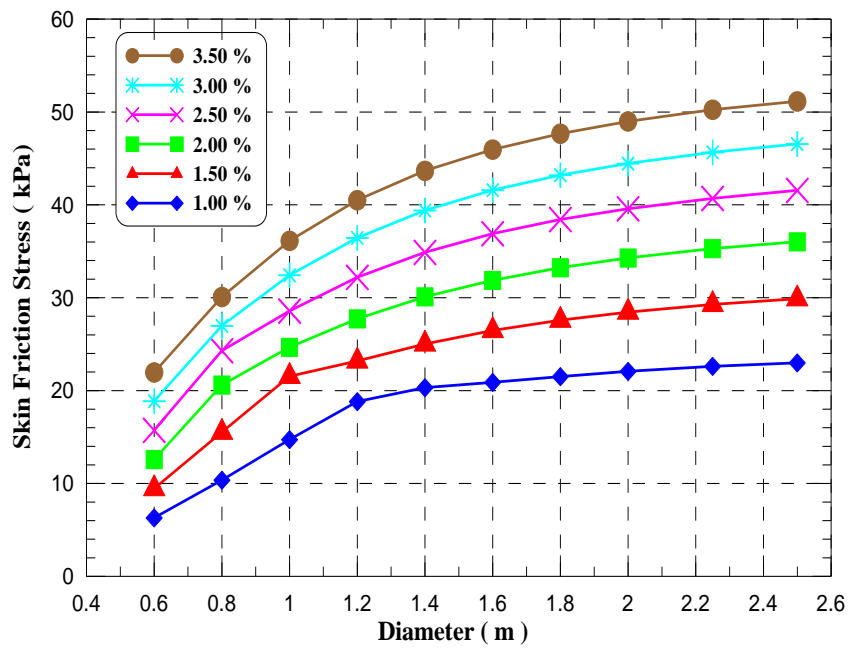

Figure (11): The Relationship between Pile Diameter and Skin Friction Stress at Different Settlement-Diameter Ratios at Pile Length Equal to $50 \mathrm{~m}$.

The portion of the soil affected by the pile according to $\mathrm{M}-\mathrm{C}$ failure criteria for piles of diameter $1.2 \mathrm{~m}$ and 1.4 $\mathrm{m}$ is shown in figure (12). As we can see increasing the pile diameter increases the affected soil along the embedded length and below the pile tip. At $(\delta / \mathrm{D})=1.0$ $\%$, increasing the pile diameter from $1.2 \mathrm{~m}$ to $1.4 \mathrm{~m}$ cause a yielding at the soil below the pile tip to a depth of about $1.20 \mathrm{~m}$ ( 0.9 of the pile diameter) and to a width of about $1.8 \mathrm{~m}$ (1.3 of the pile diameter). On the other hand, the depth and width of the affected soil increased by about $21 \%$ and $31 \%$ respectively at $(\delta / D)=3.5 \%$. Hence, it is obvious that increasing the pile diameter increases the skin friction and end bearing resistances. 


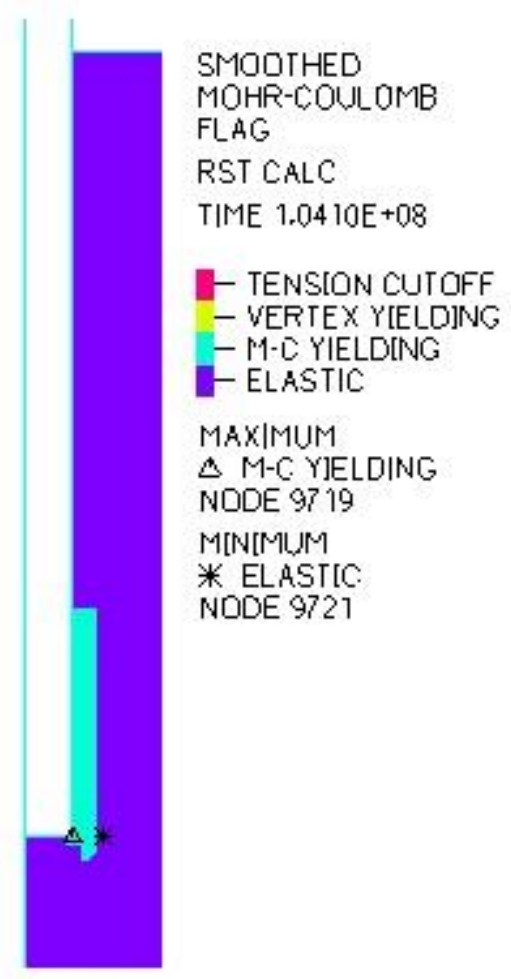

Figure (12-a): Color Shaded Contours of MohrCoulomb Failure Criteria at the Pile Tip of Pile Diameter $1.20 \mathrm{~m}$ at $(\delta / \mathrm{D})=1.0 \%$.

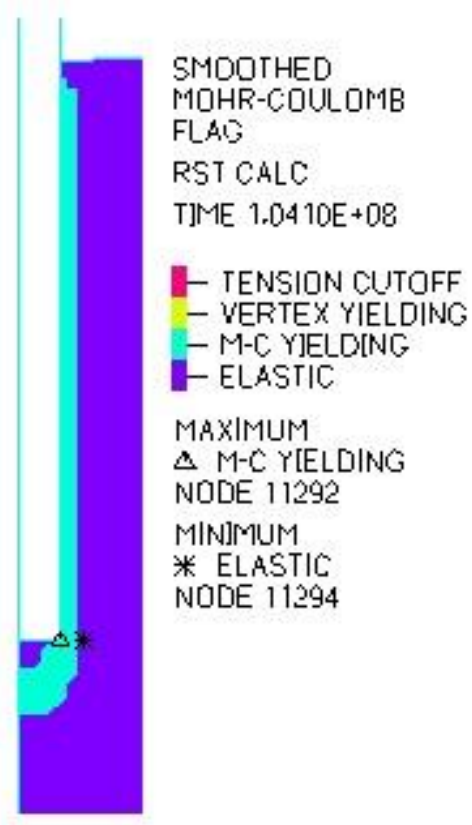

Figure (12-b): Color Shaded Contours of MohrCoulomb Failure Criteria at the Pile Tip of Pile Diameter $1.40 \mathrm{~m}$ at $(\delta / \mathrm{D})=1.0 \%$.

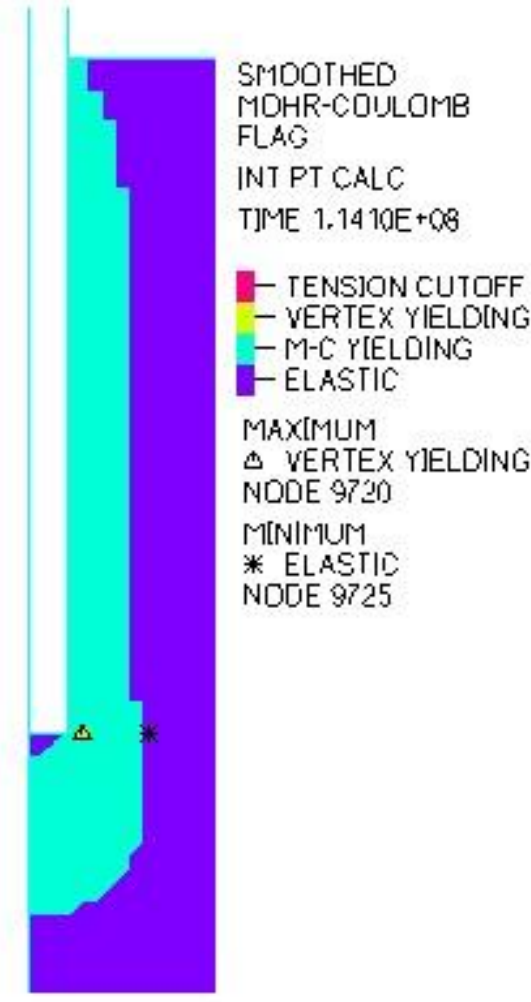

Figure (12-c): Color Shaded Contours of MohrCoulomb Failure Criteria at the Pile Tip of Pile Diameter $1.20 \mathrm{~m}$ at $(\delta / \mathrm{D})=3.5 \%$.

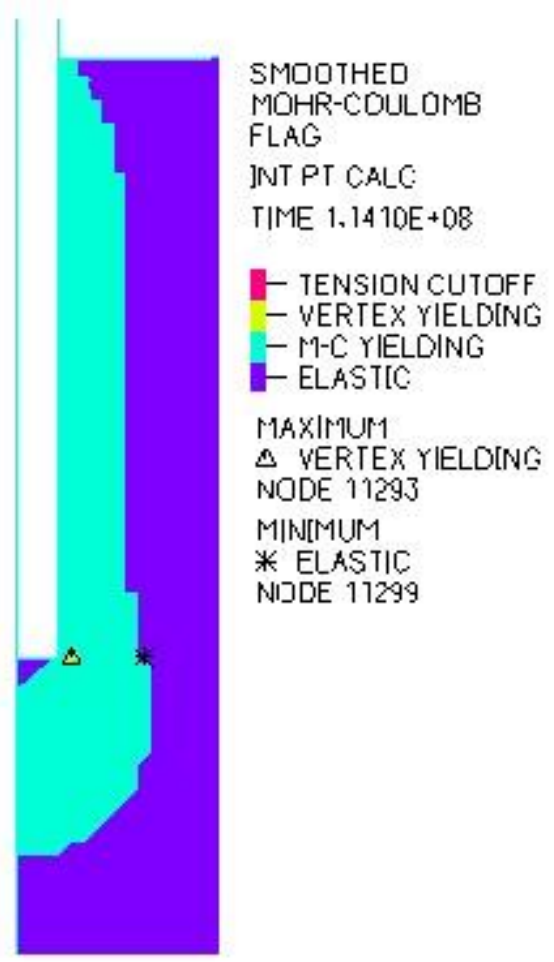

Figure (12-d): Color Shaded Contours of MohrCoulomb Failure Criteria at the Pile Tip of Pile Diameter $1.40 \mathrm{~m}$ at $(\delta / \mathrm{D})=3.5 \%$.

Figure (12): Color Shaded Contours of Mohr -Coulomb Failure Criteria of Pile Diameter $1.20 \mathrm{~m}$ and $1.40 \mathrm{~m}$ at Pile Length Equal to $50.0 \mathrm{~m}$. 


\subsection{Effect of Pile Length on the Pile Capacity}

The effect of pile length is studied for piles with lengths of $45 \mathrm{~m}, 50 \mathrm{~m}, 55 \mathrm{~m}$ and $60 \mathrm{~m}$ with embedded lengths, within the bearing sand layer, of $5 \mathrm{~m}, 10 \mathrm{~m}, 15$ $\mathrm{m}$, and $20 \mathrm{~m}$ respectively. The effect of pile length is investigated for pile diameters ranging between $0.6 \mathrm{~m}$ to $2.5 \mathrm{~m}$. Increasing the pile embedded length in the bearing layer resulted in a significant increase in the pile capacity. increasing the pile embedded length from $5 \mathrm{~m}$ to $20 \mathrm{~m}$ increases the pile capacity by about $15 \%, 40 \%, 60 \%, 75$ $\%$ and $85 \%$ for piles of diameters $0.6 \mathrm{~m}, 0.8 \mathrm{~m}, 1.0 \mathrm{~m}$, 1.20 and piles range between $1.4 \mathrm{~m}$ to $2.5 \mathrm{~m}$ respectively.

A relationship between the pile diameter and the applied load is presented in Figure (13) for $(\delta / D)=$ $1.0 \%$ at different pile embedded lengths, for different pile diameters. It is noticed that increasing the pile length has a slight effect for smaller pile diameters. However, increasing the pile diameter resulted in a significant increase in the pile load carrying capacity. Increasing the pile diameter from $0.6 \mathrm{~m}$ to $0.8 \mathrm{~m}$ to $1.0 \mathrm{~m}$ increases the pile load capacity by $7 \%, 15 \%$ and $37 \%$ respectively referred to the pile of embedded length $5 \mathrm{~m}$ and total length $45 \mathrm{~m}$. The effect of the pile length on the pile load carrying capacity can be observed for larger pile diameter for piles of diameters above than $1.20 \mathrm{~m}$. Increasing the embedded length to $10 \mathrm{~m}, 15 \mathrm{~m}$ and $20 \mathrm{~m}$ increases the pile load capacity by about $53 \%, 83 \%$ and $91 \%$ respectively for $1.4 \mathrm{~m}$ pile diameter and by about $49 \%$, $95 \%$ and $162 \%$ respectively for $2.5 \mathrm{~m}$ pile diameter. This is mainly because, the larger the pile diameter the higher skin friction and end bearing pressures it will develop.

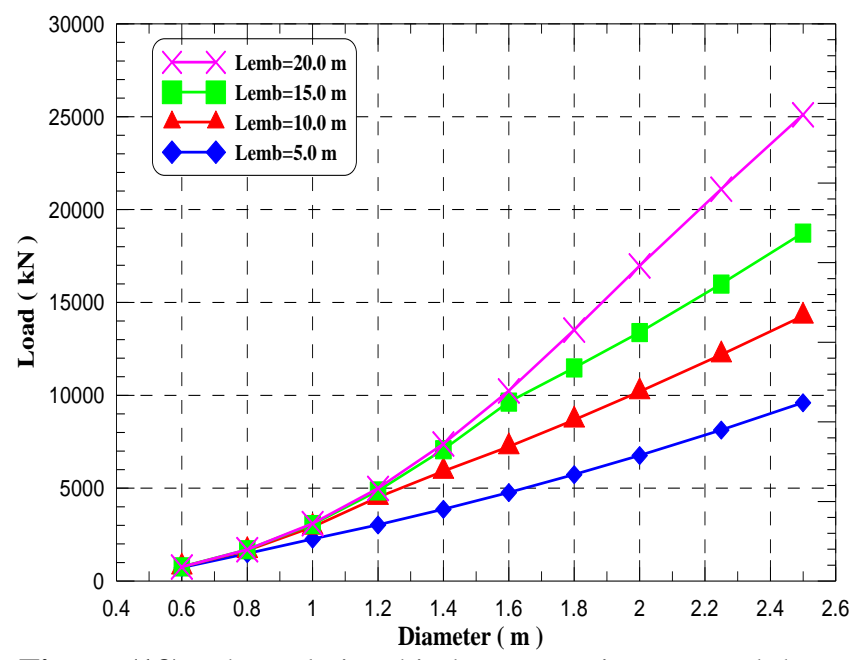

Figure (13): The Relationship between Diameter and the Applied Load at $\delta=1.0 \%$ D for Different Embedded Lengths.

The vertical stress distribution for piles of diameter $1.4 \mathrm{~m}$ and embedded length of $45 \mathrm{~m}, 55 \mathrm{~m}$ at $(\delta / \mathrm{D})=$ $1.0 \%$ are shown in Figure (14). As we can see, increasing the pile embedded length in the dense sand decreases the stress transferred by end bearing. This explains the increase of the pile load capacity due to increasing the pile length.

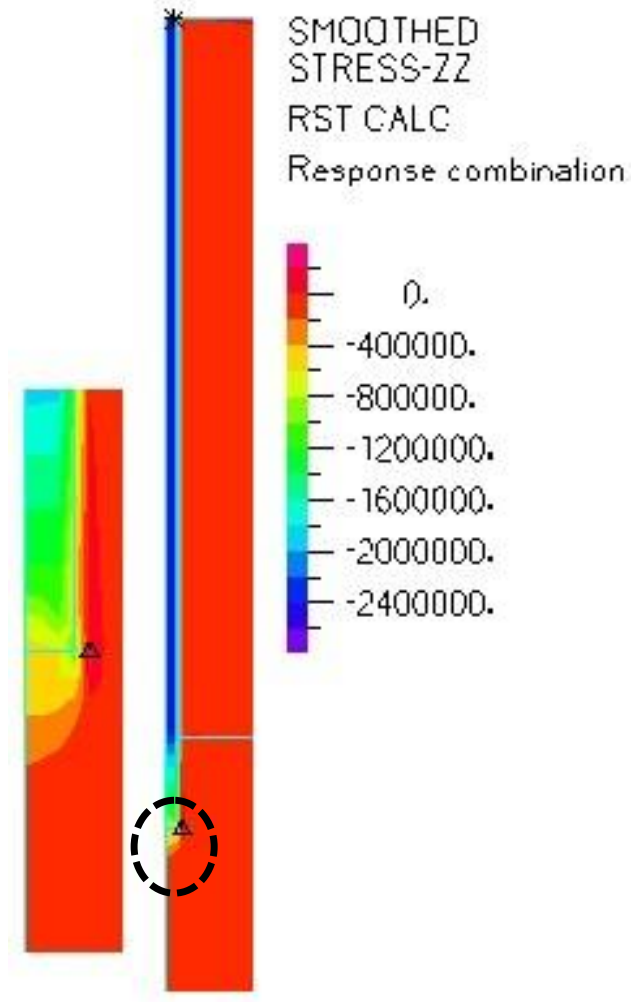

Figure (14-a): Color Shaded Contours of Vertical Stress along the Pile Length for Pile with Diameter $1.40 \mathrm{~m}$ and Length of $45 \mathrm{~m}$ at $(\delta / \mathrm{D})=1.0 \%$.

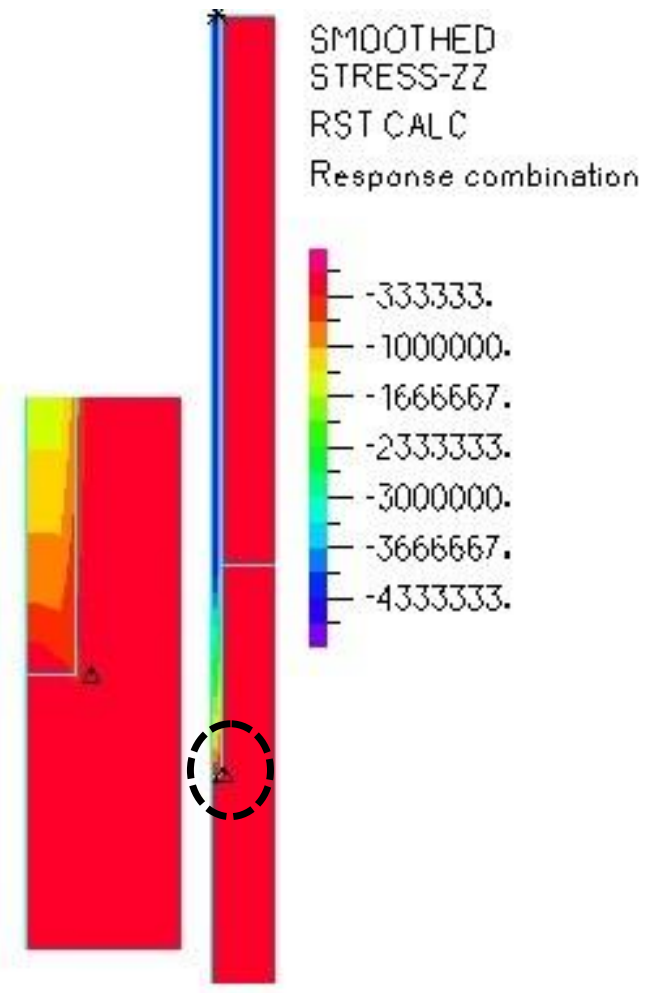

Figure (14-b): Color Shaded Contours of Vertical Stress along the Pile Length for Pile with Diameter $1.40 \mathrm{~m}$ and Length of $55 \mathrm{~m}$ at $(\delta / \mathrm{D})=1.0 \%$.

Figure (14) Color Shaded Contours of Vertical Stress along the Pile Length for Piles with Diameter 1.40 at Different Embedded Length at $(\delta / \mathrm{D})=1.0 \%$. 
The relationship between the pile diameter and the applied load at $(\delta / D)=3.5 \%$ at different pile embedded lengths is shown in Figure (15). It is noticed that the pile length still has low effect on the pile load capacity for piles of diameter $0.60 \mathrm{~m}$ and $0.80 \mathrm{~m}$ but it shows some effect for pile of diameter $1.0 \mathrm{~m}$. Increasing the pile embedded length to $10 \mathrm{~m}, 15 \mathrm{~m}$ and $20 \mathrm{~m}$ increases the pile load capacity by $42 \%, 73 \%$ and $98 \%$ respectively for pile of diameter $1.0 \mathrm{~m}$ and by about $40 \%, 80 \%$ and 120 $\%$ respectively for pile of diameter $2.50 \mathrm{~m}$. the average percentage of increasing in pile load capacity for large diameter piles of embedded length of $10 \mathrm{~m}, 15 \mathrm{~m}$ and 20 $\mathrm{m}$ are $43 \%, 80 \%$ and $111 \%$ respectively.

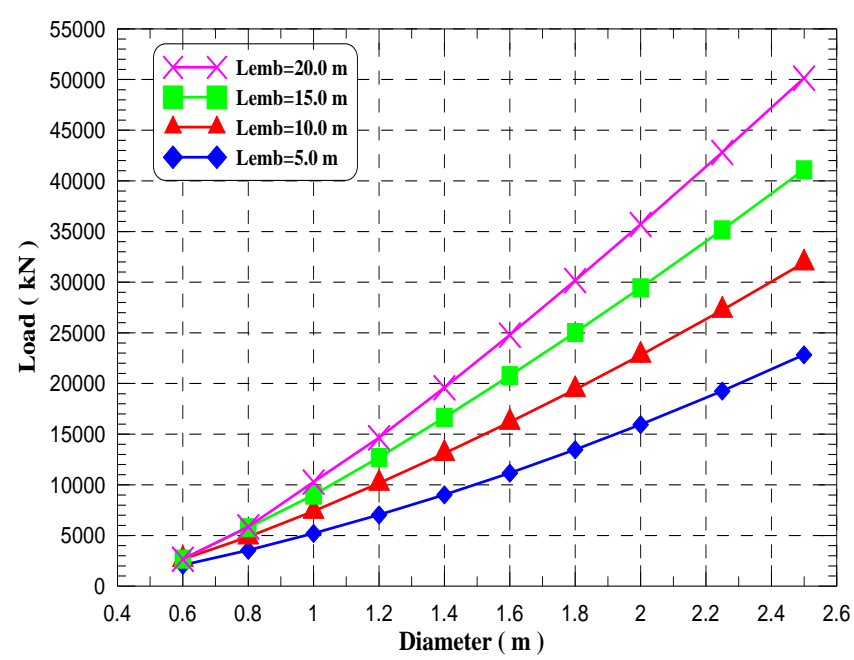

Figure (15): The Relationship between Diameter and the Applied Load at $\delta=3.5 \%$ D for Different Embedded Lengths.

The results of the numerical model for pile diameter $1.40 \mathrm{~m}$ with embedded length $5 \mathrm{~m}$ and 15 at $(\delta / \mathrm{D})=3.5$ $\%$ shows a stress concentration appeared along the pile shaft and a stress bulb appeared below the pile tip as shown in Figure (16) which indicates that soil has yielded along the pile shaft and below the pile tip. Also, a stress blub appeared below the pile tip of a depth $2.4 \mathrm{~m}$ and 1.4 $\mathrm{m}$ (1.7 and 1.0 of the pile diameter) for piles of embedded length $5 \mathrm{~m}$ and $15 \mathrm{~m}$ respectively.

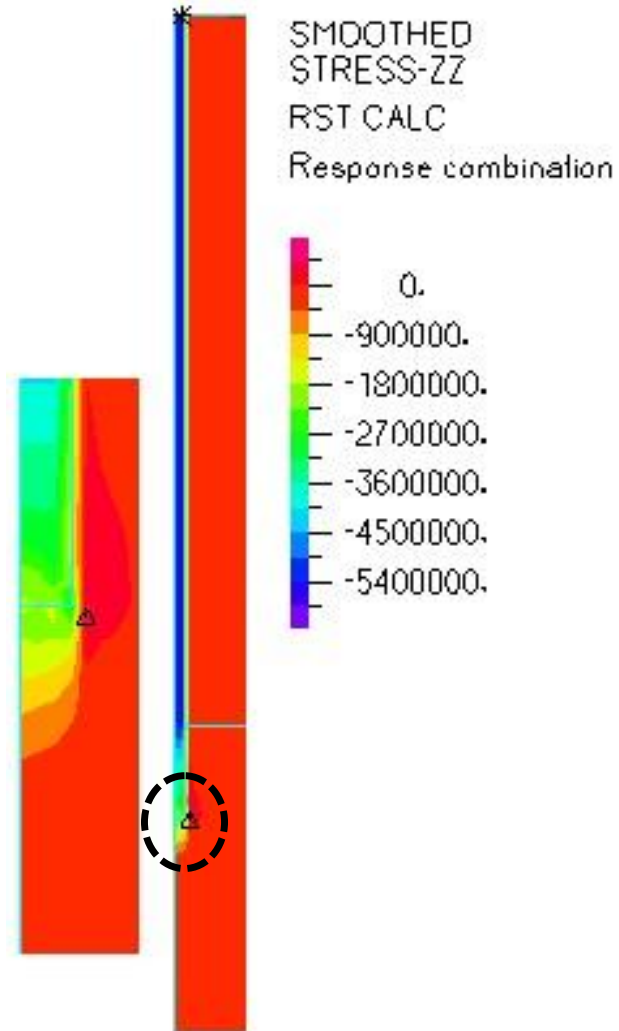

Figure (16-a): Color Shaded Contours of Vertical Stress along the Pile Length with Diameter $1.40 \mathrm{~m}$ and Length of $45 \mathrm{~m}$ at $(\delta / \mathrm{D})=3.5 \%$.

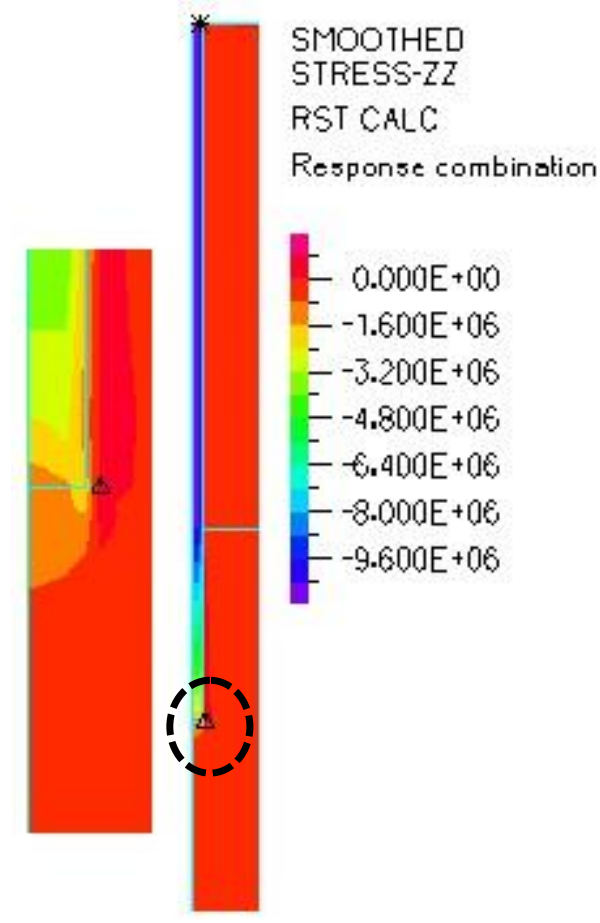

Figure (16-b): Color Shaded Contours of Vertical Stress along the Pile Length with Diameter $1.40 \mathrm{~m}$ and Length of $55 \mathrm{~m}$ at $(\delta / \mathrm{D})=3.5 \%$.

Figure (16) Color Shaded Contours of Vertical Stress along the Pile Length for Piles with Diameter $1.40 \mathrm{~m}$ for Different Embedded Length at $(\delta / \mathrm{D})=3.5 \%$. 


\section{CONCOLUSIONS}

From the numerical results performed in this study, the following conclusions can be drawn:

1. Increasing the pile diameter from $0.60 \mathrm{~m}$ to larger pile diameters has a significant effect on the pile load carrying capacity, with larger pile diameters bearing much higher loads than the smaller diameter ones. An average increase in the pile capacity of $106 \%$ is computed when increasing the pile diameter from $0.60 \mathrm{~m}$ up to $0.80 \mathrm{~m}$. Consistent increase in pile load capacities are also noticed in larger pile diameters.

2. Increasing the pile embedded length in the end bearing layer resulted in a significant increase in the pile load capacity of about $15 \%, 40 \%, 60 \%, 75 \%$ and $85 \%$ for piles of diameters $0.6 \mathrm{~m}, 0.8 \mathrm{~m}, 1.0 \mathrm{~m}$, 1.20 and piles range between $1.4 \mathrm{~m}$ to $2.5 \mathrm{~m}$ respectively as increasing the embedded length from $5 \mathrm{~m}$ to the higher value considered in this study.

3. Increasing the pile embedded length for pile of diameter $2.0 \mathrm{~m}$ from $5 \mathrm{~m}$ to $10 \mathrm{~m}, 15 \mathrm{~m}$ and $20 \mathrm{~m}$ increases the pile load carrying capacity by $51 \%, 98$ $\%, 151 \%$ respectively at a practical $(\delta / D)$ range equals $1.0 \%$. However, at ( $/ / \mathrm{D})$ equal to $3.5 \%$, the load carrying capacity is increased by $43 \%, 85 \%$ and $124 \%$.

4. None of the studied piles have exceeds the compressive design strength of the pile material which indicates that the failure is a geotechnical failure rather structural failure.

5. For large pile diameters, the failure load practically took place at $(\delta / D)$ from 4.0 to $5.0 \%$. Defining failure loads to take place at $(\delta / D)$ of $10 \%$ or even $15 \%$ is not practical at all for large diameter end bearing piles.

\section{REFERENCE}

[1] AbdelSalam, S. S., and El-Naggar, H. M., (2014), "LRFD for large-diameter bored piles in Egypt", Proc., Geo-Congress 2014: Geo-characterization and Modeling for Sustainability, pp. 900-910.

[2] ADINA R\& D, I. (2018), "ADINA Theory and Modeling Guide", Watertown, MA 02472 USA.

[3] ASTM (1994), "Standard method of testing piles under static axial compressive load", D1143-81, West Conshohocken, Pa.

[4] Bathe, K. J. (2014), "Finite Element Procedures", Edited by William Stenquist. Englewood Cliffs New Jersey. New Jersey: Prentice Hall.

[5] British Standards Institution, (1986), "British standard code of practice for foundations", BS-8004, London.

[6] Chung, J. H., Ko, J., Klammler, H., McVay, M. C ‘. and Lai, P., (2012), "A numerical and experimental study of bearing stiffness of drilled shafts socketed in heterogeneous rock", Computers \& Structures, 90, $145-152$

[7] ECP $202 / 4$, (2005), "Egyptian code for soil mechanics - design and construction of foundations", Part 4, Deep foundations, The Housing and Building Research Center (HBRC), Cairo, Egypt.
[8] Golder Associates (1979), "Geotechnical Report for Port-Said Area", Government of Port-Said, PortSaid, Egypt.

[9] Hamed, O., Mansour, M., Abdel-Rahman, A., and El-Nahhas, F., (2017), "Geotechnical characterization of Port-Said Clay", In Proc. of 19th international conference on soil mechanics and geotechnical engineering, Seoul, South Korea, 17-22.

[10] Kulhawy, F. H., and Hirany, A., (1989) "Interpretation of load testson drilled shafts", Proc., Foundation engineering: current principles and practices, ASCE, Vol (2), pp. 1132-1149.

[11]Lee, J., and Salgado, R. ,(1999), "Determination of pile base resistance in sands", Journal of Geotechnical and Geoenvironmental Engineering, 125(8), 673-683.

[12] O'Neill, M. W., and Reese, L. C., (1999), "Drilled shafts: Construction procedures and design methods", Federal Highway Administration, Washington, D.C.

[13] Radwan, A., Abdel-rahman, A., Rabie, M., and Awad-Allah, M., (2007) "New Suggested Approach for Design of Large Diameter Bored Piles Based on Finite Element Analysis", Proc., Twelfth International Colloquium on Structural and Geotechnical Engineering (12th ICSGE), Egypt, pp. 10-12.

[14] Randolph, M. F., (1978), "Theoretical study of the performance of piles",Ph.D Thesis, University of Cambridge.

[15] Smoltczyk, U., (1985), "AXIAL PILE LOADING TEST - PART 1: STATIC LOADING", Geotechnical Testing Journal Vol.(8), No. (2), pp.(79-90).

[16] Vesic, A. S., (1970), "Load transfer in pile-soil systems", Proc.,Design and Installation of Pile Foundations,Lehigh University,Bethlehem, 47-73.

[17] Weltman, A. J., \& Great Britain. Directorate of Civil Engineering Services (1980), "Pile Load Testing Procedures",Directorate of Civil Engineering Services, Property Services Agency ; London : Construction Industry Research and Information Association 